\title{
Transducin-Like Enhancer Protein 3
}

National Cancer Institute

\section{Source}

National Cancer Institute. Transducin-Like Enhancer Protein 3. NCI Thesaurus. Code C99619.

Transducin-like enhancer protein $3(772 \mathrm{aa}, \sim 83 \mathrm{kDa})$ is encoded by the human TLE3 gene. This protein is involved in the repression of transcription. 